Egyptian Journal of Aquatic Biology \& Fisheries Zoology Department, Faculty of Science,

Ain Shams University, Cairo, Egypt.

ISSN 1110 - 6131 Vol. 22(1): 1-14 (2018)

ejabf.journals.ekb.eg

Indexed in Scopus

\title{
Molecular and biometric characterizations of the Western king prawn Melicertus latisulcatus (Kishinouye, 1896) in the Egyptian Red Sea.
}

Eman M. Abbas' ${ }^{1}$ Khaled M. Geba ${ }^{2}$ and Zaki Z. Sharawy*3

1. Genetic and Genetic Engineering Lab, Aquaculture Division, National Institute of Oceanography and Fisheries (NIOF), Qaitbay, Alexandria, Egypt.

2. Genetic Engineering and Molecular Biology Division, Faculty of Science, Menoufia University, Egypt.

3. Invertebrates Lab, Aquaculture Division, National Institute of Oceanography and Fisheries (NIOF), Suez, Egypt.

*Corresponding Author, zaki_sharawy@yahoo.com

\section{ARTICLE INFO}

Article History:

Received: Dec. 4, 2017

Accepted: Jan. 2, 2018

Available online: Feb. 2018

\section{Keywords:}

Melicertus latisulcatus

Red Sea

Biometrics

Genetics barcodes

Molecular study

\section{ABSTRACT}

Although the western king prawns Melicertus latisulcatus (Kishinouye, 1896) are among the highly-priced shrimp species in the world, there is a great shortage in research dealing with both morphological and molecular clues for the identification of these species. Therefore, the morphological study was designed to provide a full morphological description of this important species. The morphometric analysis proved the variability of the relative growth between sexes suggesting that length-weight relationships could be used as important criteriafor selective breeding programs. For molecular identification DNA was extracted from the samples to provide genetic barcodes of this species using polymerase chain reaction (PCR)-amplification of 16SrRNA and cytochrome oxidase subunit 1 (COI) genes. The results clearly showed that, the Egyptian M. latisulcatus speciesis genetically closely related toall Melicertus species, while both barcoding and phylogeny of this species resulted in clear species discrimination. Furthermore, the samples identified in the current study seem to belong to a single origin, differing from those from other geographical locations where the species was found.Overall, this study suggested a valuable tool for assessment of prawn populationsat both fisheries and genetic levels, providing a toolfor managementas well as for the optimization of its aquaculture.

\section{INTRODUCTION}

Penaeid shrimps and prawns have a worldwide distribution in both the tropics and the subtropicsregions with a global catch of 3.4 million tonnes/year, with more than half of it is originated from both Western and Northwest Central Pacific and other essential fisheries are in the Indian Ocean and in the Western Atlantic Ocean (FAO, 2014). However, the greatest differences of thePenaeidae's family are the preferred habitats of their different stages; either they are predominantly estuarine in/offshore, demersal or pelagic (Dall et al., 1990). Such benthic prawn prefers a sandy to seagrass or vegetated habitats (Tanner and Deakin, 2001). 
Prawn juveniles and adults show a strong diel behavioral pattern of daytime burial and nocturnal activity (Primavera and Lebata, 2000), where higher catchability is greater during the lunar cycle as well as warmer months.

Moreover, the abundance of it within the waterbody is influenced by salinity, where more abundance is associated with salinities above 30 psu (Dixon et al., 2011).

The western king prawn was previously classified as Penaeus latisulcatus, kishinouye (1896). In 1997, Pérez Farfanteand Kensley suggested a taxonomic redactionusing the former subgenera in the genus Penaeus to a generic rank; replacing Penaeus with Melicertus. In 2007, Flegelrefined the taxonomic name, claiming confusion raised using Pérez Farfante and Kensley's taxonomic revisions, and proposed to include a statement in brackets after the new binomial the first time it is mentioned as Penaeus (Melicertus) latisulcatus.

The Egyptian Red Sea includes two Gulfs (Suez and Aqaba) and the intervening Sinai Peninsula witha total length of about $1500 \mathrm{~km}$. According to the General Authority of Fish Resource Development (GAFRD, 2014), the annual Egyptian commercial fisheries and aquaculture production of shrimp and prawnare 21804 tonnes distributed as 7235, 4562, 8061 and 1946 tonnesfrom aquaculture, Lakes, Mediterranean and Red Seas, respectively.

Basically, adult prawns exploit the offshore during the breeding phase where drift and growth of larvae occur, while the settlement of postlarvae and their development to juvenile stage occur in the estuaries (inshore phase). Such deviation can be a cause of the conflict between postlarvae, juvenile. In addition, fishermen were claiming that their right in fishing areas is being breached. To make the matter worse, more pressure has been developed, that the immigrating postlarvae and adults are collected for sale to commercial prawn farms as a seed stock or even as a source of seed. The deviation is not recorded in the Red Sea species.

The Suez Gulf is one of the most productive wild fishing areas in the Egyptian Red Sea. It contains a huge variety of fish, molluscs and crustaceans of its commercial catch, prawnand shrimp are the most important commercial species representing about 7\% of the total trawl landings (El-GanainyandYassien, 2012). Based on shrimp and prawn commercial sizes, they are categorized by fishers to small (Trachysalambriacurvirostris and Metapenaeopsisstridulans) and large categories (Melicertu slatisulcatus, Penaeus semisulcatus, and Marsupenaeus japonicas).

Melicertu slatisulcatus, kishinouye, 1896 (formerly Penaeus (Melicertus) latisulcatus) is the most economically important prawns in both wild fisheries and aquaculture; due to their larger size compared with other shrimp and prawnspecies in the Gulf of Suez. Furthermore, it is a dominant andimportant species in the Egyptian Red Sea production. Despite their economic importance in Egypt, there are no studies about its molecular identification as well as the morphological characters. Furthermore, a survey of the literature shows that onlya fewstudies have been conducted concerning its morphometry in Egypt (Yasin, 1992; Zaglol, 1995; AbdelRazek et al., 1996; El-Ganainy and Yassien, 2012) as well as in different regions around the world (Penn and Hall, 1974; Ivanov and Krylov, 1980; Farmer, 1986; Potter et al., 1991; Kangas, 1999; Carrick, 2003; Sundaramoorthyet al., 2013).

DNA barcoding is a technique that was originally set to assign unknown samples to certain species and to enhance the discovery of new species. It mainly relies on the retrieval of a standard short inter-specifically hypervariable sequence of the genome, the barcode, and comparing this to a database of known reference sequences of known identity (Hajibabaei et al., 2007). Until now, the $5^{\prime}$ region of the 
mitochondrial cytochrome oxidase subunit 1 (CO1) gene is the universal standard barcode for animals (Hajibabaei et al., 2007). Therefore, DNA barcoding was successfully used in resolving several issues related to aquatic and terrestrial animals discrimination. The concept of DNA barcoding resulted in significant advances in complicated issues related to the taxonomy of the species, mainly biodiversity description in the given regions; characterization of cryptic species; elucidation a similar phenotypic species and life history polymorphism (Tavares et al., 2017). Genetic identification of decapods, especially when coupled to the morphological description, is gaining wide popularity; due to the morphological similarity in this group, besides its economic importance (Sharawyet al., 2017). Our team members are directly involved in both morphological and genetic description, and authentication of the Egyptian decapod species that exist within the Egyptian territories, being either autochthonous or allochthonous species (e.g. Abbas et al., 2016; Sharawy et al., 2017). Again, as M. latisulcatus is the most economically important species for the Egyptian capture fisheries in the Suez Gulf, it has been of a prime importance to develop both molecular and morphological tools for its exploration and authentication. In the current study, M. latisulcatus was subjected to DNA barcoding through isolation, polymerase chain reaction (PCR) amplification and sequencing of the 5 hypervariable barcode region of $\mathrm{CO} 1$ gene, alongside with conducting various morphological measurements over it, in order to verify and authenticate it as a major member of the Egyptian economic shrimps and prawn species.

\section{MATERIALS AND METHODS}

\section{Sampling and biometric analyses:}

From November 2014 to October 2015, a total of 2865 individuals (987 males and1878 females) of $M$. latisulcatus were freshly monthly collected from the commercial catch of the Red Sea. Samples were immediately transferred to the National Institute of Oceanography and Fisherieslaboratories, Suez, Egypt on ice boxes where the measurements were carried out.

To avoid bias due to different measuring tools, or due to human errors, and seeking more accuracy (Sharawy et al., 2017), individual lengths were measured to the nearest $0.1 \mathrm{~cm}$ applying a Matlab routine (The Math works, Inc., Natick, MA) on the individual prawn snapshot that has been taken using a USB camera (Leica MEGA 0.I.S) equipped with a DC VARIO-ELMARIT 1:2.8-4916.3-25.2 ASPH lens. The snapshots were stored for further measurements or for double check whenever needed.However, only prawns with complete rostrum have been manually straightened on millimeter paper to avoid the natural curvature of prawn body. The measurements were defined as: a) total length (TL,cm); from tip of the rostrum to the end of the telson, b) carapace length $(\mathrm{CL}, \mathrm{cm})$; distance from the posterior margin of orbit to the posterior edge of the carapace, c)carapace width $(\mathrm{CW}, \mathrm{cm})$, greatest width of the point of last dorsal rostral toothand d) the wet weight (Wt, g) that was weighed by electronic digital balance (Sartorius $\pm 0.01 \mathrm{~g}$ ).

The external morphological characteristics of prawns; the carapace and its spines, the rostrum together with its dorsal and ventral teeth, the ridges, the grooves, telson, appendages and their segments, and the different sexual characteristics, were identified. Thereafter, they were compared to those in the literature; in order to confirm the identification (e.g. Pérez Farfante and Kensley, 1997; Nizinski, 2003).

The Following equation was used to establish the length-weight relationships: $\mathrm{Wt}=\mathrm{a} \mathrm{TL}^{\mathrm{b}}$, where TListhe total length in $\mathrm{cm}$ andWtisthe total body weight (wet 
weight) in $g$, whilea and $b$ are constants. Meanwhile, the length-weight parameters were estimated by fitting a nonlinear model while the length-length parameters were estimated by fitting a linear model in PASW statistics 18 software package.

\section{DNA extraction and PCR amplification:}

Briefly, 100-250 mg of muscle tissue samples were excised and homogenized in TES buffer (10 mMTris- $\mathrm{HCl}, 140 \mathrm{mMNaCl}, 25 \mathrm{mM}$ EDTA, $\mathrm{pH}$ 7.8) that contained $1 \%$ SDS and $0.5 \mathrm{mg} \mathrm{mL}^{-1}$ proteinase $\mathrm{K}$. The homogenates were incubated for one hour at $50{ }^{\circ} \mathrm{C}$. The genomic DNA was then extracted from each sample as described in (Sambrook et al., 1989) using theconventional phenol-chloroform procedure. The resulting DNA was dissolved in TE buffer (100 mMTris-HCl, 10 mM EDTA, pH 8). DNA was then stored at $4{ }^{\circ} \mathrm{C}$ and its concentration was estimated by NanoDrop (Biodrop, England).

The partial coding regions of cytochrome oxidase subunit 1 (COI) gene were amplified by PCR (Veriti Thermal cycler, Applied Biosystems, USA) using the set of primers, described by Folmer et al. (1994), which are LCO1490 (5'GGTCAACAAATCATAAAGATATTGG-3') and HCO2198 5'TAAACTTCAGGGTGACCAAAAAATCA-3'). The amplification reaction was set up as $20 \mathrm{ng}$ of template DNA from each sample, $1 \mathrm{X}$ MyTaq ${ }^{\mathrm{TM}} \mathrm{HS}$ Red Mix (Bioline, London, UK), $0.4 \mu \mathrm{M}$ each of primer, in a total volume of $25 \mu \mathrm{L}$. However, the PCR was initially denatured for $5 \mathrm{~min}$ at $94^{\circ} \mathrm{C}$, and then by 15 cycles of denaturation for 1 min at $94^{\circ} \mathrm{C}$ annealing for $1 \mathrm{~min}$ at $40^{\circ} \mathrm{C}$, extension for $1 \mathrm{~min}$ at $72^{\circ} \mathrm{C}$, and 25 cycles of denaturation for $1 \mathrm{~min}$ at $94^{\circ} \mathrm{C}$ annealing for $1 \mathrm{~min}$ at $45^{\circ} \mathrm{C}$, extension for $1 \mathrm{~min}$ at $72^{\circ} \mathrm{C}$, and a final elongation at $72^{\circ} \mathrm{C}$ for $7 \mathrm{~min}$ in a GeneAmp PCR System 9700 (Applied Biosystems, California, USA).

The 16S rRNA gene partial fragments were amplified using the 16Sbr universal primer (5'-CCGGTCTGAACTCAGATCACGT-3'), and 16Sar (5'CGCCTGTTTATCAAAAACAT-3') set. The amplification $(25 \mu \mathrm{l})$ contained $1 \mu \mathrm{l}$ DNA and $12.5 \mu \mathrm{l}$ PCR-Master Mix, $0.4 \mu \mathrm{M}$ each of primer. The PCR amplification consisted of an initial denaturation at $94^{\circ} \mathrm{C}$ for $4 \mathrm{~min}$ followed by 35 cycles of denaturation at $94^{\circ} \mathrm{C}$ for $1 \mathrm{~min}$, annealing at $48^{\circ} \mathrm{C}$ for $1 \mathrm{~min}$, extension at $72^{\circ} \mathrm{C}$ for $1.30 \mathrm{~min}$, and a final extension at $72^{\circ} \mathrm{C}$ for $7 \mathrm{~min}$.

The amplified products were visualized using $1.4 \%$ agarose gel electrophoresis stained by $25 \mu \mathrm{g}$ of ethidium bromide. The produced singular bands at the expected band sizes for each sample were purified using Isolate II PCR and Gel Extraction Kit (Bioline, London, UK). The purified DNA fragments were subjected to sequencing, which was performed using the Big Dye Terminator version. 3.1 Cycle Sequencing kit (Applied Biosystems) and ABI3730 Sequencer (Applied Biosystems, California, USA).The sequencing PCR reaction was performed at $96^{\circ} \mathrm{C}$ for $2 \mathrm{~min}$, followed by 25 cycles of $10 \mathrm{sec}$ at $96^{\circ} \mathrm{C}, 5 \mathrm{sec}$ at $50^{\circ} \mathrm{C}$ and 4 minutes at $60^{\circ} \mathrm{C}$.

\section{DNA sequencing and phylogenetic analysis:}

The resulting raw sequences of COI and 16S rRNA genes were edited by the Chromas Lite software version 2.1 (Technelysium- Pty Ltd, available from the URL http://technelysium.com.au/). The partial coding sequences for COI gene and/or the 16SrRNA sequences of the Egyptian samples of M. latisulctus were compared to the GenBank database using BLAST algorithm. COI sequences for M. latisulctus and other species of the genus Melicertus that areavailable in the GenBank database were retrieved from GenBank database and aligned using Clustal W software (Thompson et al., 1994) included in the MEGA6 software package (Tamura et al., 2013). These sequences came from Melicertus latisulcatus, M. canaliculatus, M. kerthurus, $M$. plebejus, M. hathor, M. margiatus, Farfantepenaeusaztecus, $F$. brasiliensis, $F$. 
paulensis, Fenneropenaeus indicus, F. merguiensis, F. penicillatus, Hymenopenaeus debilis, Litopenaeus vannamei, and Marsupenaeu s japonicus. The aligned sequences were either used for calculation of pairwise distances or saved as fasta format. Then, the fasta file was exported to JModel-Test software V. 2.1.10 for finding the fit nucleotide substitution model to construct the maximum likelihood phylogenetic tree. Then, the fasta file was uploaded to Beauti software V. 1.8.3. To determine the substitution model, the JModel-Test was used and Markov chains (10.000.000) were selected. This number of Markov chains was used once and the program ran again twice with 50.000.000, and 100.000.000 chains. To estimate the tree topologies, BEAST software V. 1.8.3 was used with the XMLfiles. The log files resulted from the three trials was uploaded to the program Tracer v1.6; to evaluate the quality of the results and the only accepted results were that above 200 Effective Sample Size (ESS). LogCombiner software V. 1.8.3 was used to combine the results from the trees, and then it was uploaded, to Tree Annotator software V. 1.8.3; in order to summarize the information that was retrieved from tree samples and created by BEAST. The FigTree software V. 1.4.2 was applied to obtain the final consensus tree.

\section{RESULTS}

\section{Morphology of M. latisulcatus:}

The body of $M$. latisulcatus has pink toreddishcolor in adults, while the abdominal segments have ashort vertical dark bar on pleuron with 2 dark stripes on the right angle of the carapace too.The carapaceis uniformly glabrous and has no longitudinal sutures with very distinct grooves and crests that bearing both gastrofrontalcarina and hepatic crests. The rostrum is well developed, straight and slightly curved at the tip, and armed with 9-12 dorsal teeth and 1 ventral tooth. Its postrostral crest is well developed with a deep median groove through it, while the adrostral groove is extended to the posterior margin of the carapace, which is wider than the postrostral crest, while the posterior end of thegastro-frontal groove is visiblydivided into two parts (Fig. 1).

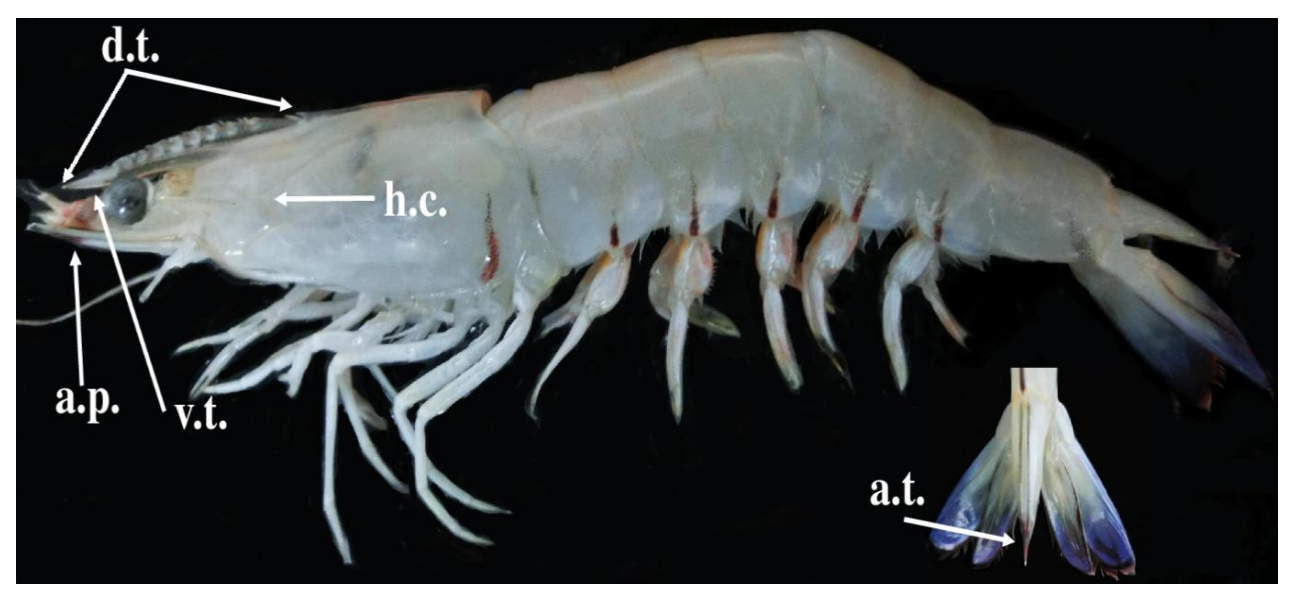

Fig. 1:Lateral view ofwestern king prawn shows the antennal peduncle (a.p.), dorsal teeth (d.t.), ventral tooth (v.t.), and hepatic crest (h.c.) together with its dorsal view of armed telson (a.t.) and tail fan.

Prawns petasma has an involute pod-like structure, in which the dorsomedial lobules are united along midline, while the dorsolateral lobules are reaching, distally, thesame level as ventromedial lobules below the tip of dorsomedial lobules. Prawn 
males have subtriangular appendix masculine with a curved lateral surface and rounded apex.

The anterior portion of thelycum is consisting of well-calcified swelling with strongly branched apical projections into apair of flattened round-tipped horns between thefourth pair of pereiopods. The posterior portion contains two almost concave lateral plates that meeting along themidline, which forming the seminal receptacles.Overall, the abdomen isdorsally carinated from theposterior half of thefourth segment to thetip of sixth while the telson has 3 pairs of movable lateral spines (Fig. 2).

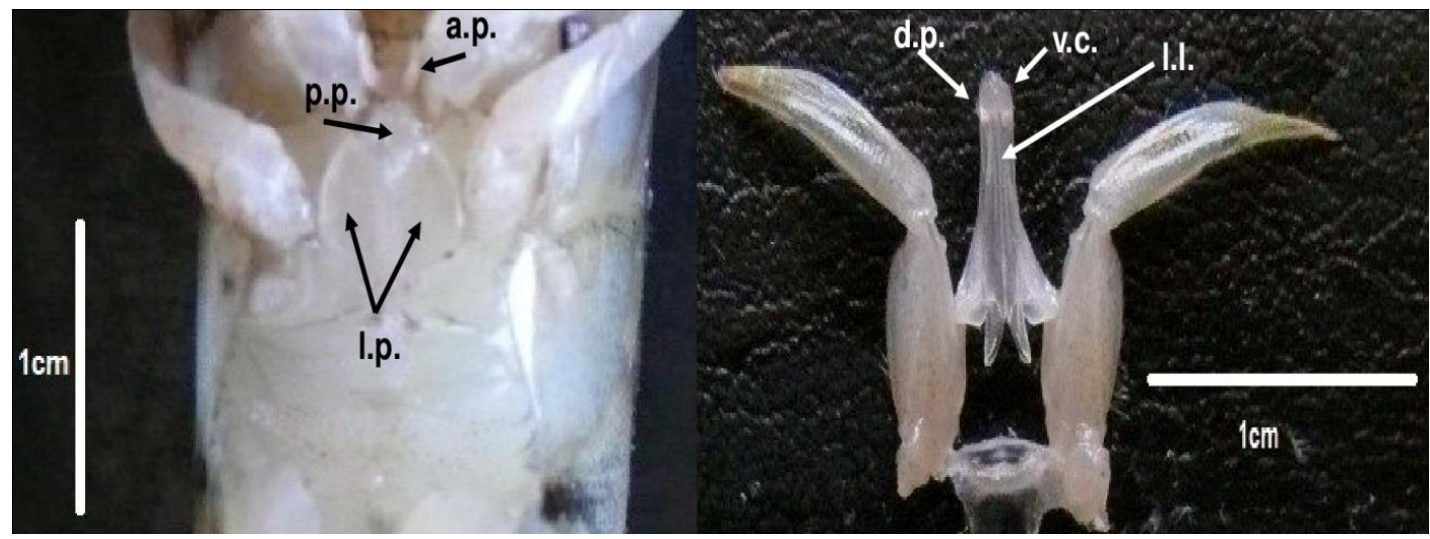

Fig. 2: Dorsal view of thelycum (left) shows the anterior process (a.p.), the posterior process and the lateral plates (l.p.), and petasma photographs (right) shows the distomedian projections (d.p.), the ventral costae (v.c.) and the lateral lobules (1.l) of the western king prawn collected from the Gulf of Suez, Red Sea from November 2014 to October 2015.

\section{Morphometric characteristics and Size distribution:}

Specimens from all sampling dates were pooled by sex to determine relationships between lengths as well as length-weight relationships. The morphometric relationships equations (length-length relationships) computed for 987 males and 1878 females as:

\section{Total length-carapace length (TL-CL) relationships}

For males: $\mathrm{CL}=0.3477 \mathrm{TL}+0.072( \pm 0.003)\left(\mathrm{r}^{2}=0.938\right)$

For females: $C L=0.3643 T L-0.098( \pm 0.007)\left(r^{2}=0.950\right)$

\section{Carapace length-carapace width $(\mathrm{CL}-\mathrm{CW})$ relationships}

For males: $\mathrm{CW}=0.2994 \mathrm{CL}+0.025( \pm 0.002) \quad\left(\mathrm{r}^{2}=0.793\right)$

For females: $\mathrm{CW}=0.3356 \mathrm{CL}-0.112( \pm 0.009)\left(\mathrm{r}^{2}=0.829\right)$

While the relationships between the total weight $(\mathrm{Wt})$ and both total length (TL) as well ascarapace length (CL) are presented in Table (1). The TL-Wtnonlinear regression analysis for males and females showedthat the slopes were significantly differed between sexes (Kolmogorov-Smirnov test, $\mathrm{p}<0.001$ ). Females were increasingly heavier than males with growing TL. Meanwhile the linear regressions of TL on CL were also significant for both sexes, total length scaled isometrically to $\mathrm{CL}$ in males and negatively in females. It shows that males body proportion change constantly but increased in females, i.e., in large females the CL (abdomen) were relatively shorter in comparison with the small ones. 
Table 1: Published studies estimates of length-weight relationship equations of western king prawn Melicertuslatisulcatus (in chronology order).

\begin{tabular}{|c|c|c|c|}
\hline Author & Equation & Region & Year \\
\hline Penn and Hall, 1974 & $\begin{array}{ll}\text { Male: } & \mathrm{Wt}=0.000847 \mathrm{CL}^{2.899} \\
\text { Females: } & \mathrm{Wt}=0.000156 \mathrm{CL}^{2.701}\end{array}$ & Shark Bay, Western Australia & - \\
\hline Ivanov and Krylov 1980 & $\begin{array}{lll}\text { Male: } \quad \mathrm{Wt}_{\mathrm{t}}=0.0000101 \mathrm{~L}^{2.96} & (\mathrm{r}=0.99, \mathrm{n}=11) \\
\text { Females: } & \mathrm{Wt}=0.000103 \mathrm{~L}^{2.53} & (\mathrm{r}=0.95, \mathrm{n}=37) \\
\text { Sex combined: } \mathrm{Wt}=0.00189 \mathrm{~L}^{2.85} & (\mathrm{r}=0.96, \mathrm{n}=48) \\
\text { Male: } \quad \mathrm{Wt}=0.001612 \mathrm{I}^{2.70} & (\mathrm{r}=0.972, \mathrm{n}=23) \\
\text { Females: } & \mathrm{Wt}=0.00998 \mathrm{I}^{2.20} & (\mathrm{r}=0.95, \mathrm{n}=57) \\
\text { Sex combined: } \mathrm{Wt}=0.00753 \mathrm{I}^{2.28} & (\mathrm{r}=0.97, \mathrm{n}=80)\end{array}$ & Western Indian Ocean & Dec. 1975/April 1976 \\
\hline Farmer 1986 & $\begin{array}{|lc|}\text { Male: } & \mathrm{Wt}=\exp (0.00195+2.746 \log \mathrm{CL}+\mathrm{e} \\
\text { Females: } & \mathrm{Wt}=\exp (0.00265+2.648 \log \mathrm{CL}+\mathrm{e} \\
\end{array}$ & Arabian Gulf & - \\
\hline Potter et al 1991 & $\begin{array}{|lll|}\text { Male: } & \mathrm{Wt}=2.617 \log C L^{2.633} & \left(\mathrm{r}^{2}=0.97, \mathrm{n}=1580\right) \\
\text { Females: } & \mathrm{Wt}=2.532 \log C L^{2.508} & \left(\mathrm{r}^{2}=0.95, \mathrm{n}=1140\right) \\
\end{array}$ & Pee-Harvey Estuary, south-western Australia & May 1985/April 1988 \\
\hline Yassein 1992 & $\begin{array}{llc}\text { Male: } & \mathrm{Wt}=0.00448 \mathrm{TL}^{3.193} & (\mathrm{r}=0.999, \mathrm{n}=1083) \\
\text { Females: } & \mathrm{Wt}=0.00375 \mathrm{TL}^{3.275} & (\mathrm{r}=0.999, \mathrm{n}=1183) \\
\text { Sex combined: } \mathrm{Wt}=0.00345 \mathrm{TL}^{3.299} \quad(\mathrm{r}=0.96, \mathrm{n}=2266)\end{array}$ & Suez Gulf, Red Sea & Feb. 1984/Dec. 1986 \\
\hline Zaglol 1995 & $\begin{array}{|lll|}\text { Male: } & \mathrm{Wt}=0.167 \mathrm{CL}^{2.782} & \left(\mathrm{r}^{2}=0.999, \mathrm{n}=350\right) \\
\text { Females: } & \mathrm{Wt}=0.152 \mathrm{CL}^{2.865} & \left(\mathrm{r}^{2}=0.998, \mathrm{n}=378\right) \\
\end{array}$ & Suez Gulf, Red Sea & $1990 / 1991$ \\
\hline Kangas (1999) & Juvenile: $\mathrm{Wt}_{\mathrm{t}}=0.000662 \mathrm{CL}^{2.908}$ & Port Wakefield, Gulf St Vincent & April 1997 \\
\hline Carrick (2003) & $\begin{array}{ll}\text { Male: } & \mathrm{Wt}=0.000124 \mathrm{CL}^{2.76} \\
\text { Females: } & \mathrm{Wt}=0.000175 \mathrm{CL}^{2.66}\end{array}$ & Spencer Gulf & - \\
\hline El-Ganainy and Yassien (2012) & Sex combined: $\mathrm{Wt}=0.2615 \mathrm{CL}^{2.6875}$ & Suez Gulf, Red Sea & - \\
\hline Sundaramoorthy et al 2013 & Sex combined: $\mathrm{Wt}=0.00418 \mathrm{TL}^{3.003}$ & Thoothukudi coast, Southeast India & April 2006/March 2008 \\
\hline Recent study & $\begin{array}{|ll|}\text { Male: } \quad \mathrm{Wt}=0.0044 \mathrm{TL}^{3.14} & \left(\mathrm{r}^{2}=0.956, \mathrm{n}=987\right) \\
\text { Females: } \mathrm{Wt}=0.0038 \mathrm{TL}^{3.21} & \left(\mathrm{r}^{2}=0.975, \mathrm{n}=1878\right) \\
\text { Sex combined: } \mathrm{Wt}=0.0039 \mathrm{TL}^{3.20} & \left(\mathrm{r}^{2}=0.969, \mathrm{n}=2865\right) \\
\text { Male: } \quad \mathrm{Wt}=0.134 \mathrm{CL}^{3.06} & \left(\mathrm{r}^{2}=0.952\right) \\
\text { Females: } \mathrm{Wt}=0.135 \mathrm{CL}^{3.05} & \left(\mathrm{r}^{2}=0.941\right) \\
\text { Sex combined: } \mathrm{Wt}=0.132 \mathrm{CL}^{3.063} & \left(\mathrm{r}^{2}=0.969\right) \\
\end{array}$ & Suez Gulf, Red Sea & Nov. 2014/Oct. 2015 \\
\hline
\end{tabular}

Furthermore, the ratio between CW:TL was plotted on TL to investigate the deference's in body proportion between males and females. Males and females grew constantly (same trends) up to $10.3 \mathrm{~cm}$ TL $(=3.9 \mathrm{~cm} \mathrm{CL})$ (Fig.3). In contrast, the ratio has been decreased in males while it increased constantly in females where the abdomen suddenly broadened, indicating amorphological shift between immature and mature females.

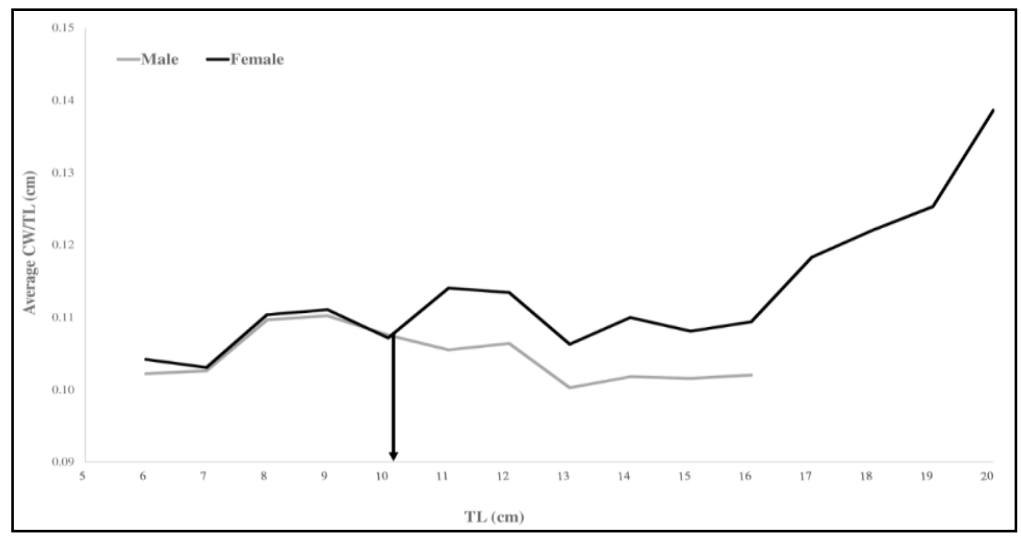

Fig. 3: Average Carapace width divided by total length (CW/TL) on total length (TL) for males and females western king prawn collected from the Seuz Gulf, Red Sea from November 2014 to October 2015.

Overall, a total number of individuals analyzed for this study was 2865 individuals, females dominated the catch with $65.6 \%$ (1878 individuals) while $34.4 \%$ were males with 987 individuals (1.9:1 ratio). Males were on average smaller (TL ranged from $6.3 \mathrm{~cm}$ to $17.0 \mathrm{~cm}$ ) than females (TL ranged from $7.3 \mathrm{~cm}$ to $20.2 \mathrm{~cm}$ ), the mean TL was $13.4 \pm 1.7 \mathrm{~cm}$ ( \pm sd) and $14.7 \pm 2.8 \mathrm{~cm}( \pm \mathrm{sd})$ for males and females, respectively. The mean TL of females was $3.2 \mathrm{~cm}$ longer than that of males. Males and females of the smallest size class $(6.0-11 \mathrm{~cm})$ have been observed only during the cold seasons, especially during the winter. 
The overall mean weight $(\mathrm{Wt})$ of females were14 $-20 \%$ heavier than that of male prawns; the mean Wt was $16.6 \pm 2.3 \mathrm{~g}$ and $23.4 \pm 3.1 \mathrm{~g}$ for male and female prawns, respectively. Minimum and maximum Wt were $1.2 \mathrm{~g}, 40.7 \mathrm{~g}, 2.3 \mathrm{~g}$ and $68.3 \mathrm{~g}$ for males and female prawns, respectively.

Molecular identification:

The COI sequences of the Egyptian Red Sea M. latisulcatus were deposited in GenBank/EMBL/DDBJ databases with accession numbers LC189472.1, LC189473.1, and LC189476.1-LC189481.1. This was carried out according to the morphological identification, BLAST comparisons for the obtained sequences with their counterparts in the GenBank database, and the phylogenetic tree's results, as well be mentioned. No COI sequences for COI barcode region were found in the GenBank database. The present sequences showed 99\% similarity with M. hathor (acc. no. KU950454.1). Much lower similarities were found with other species of family Penaeidae, including, for example, $86 \%$ 88\% with Marsupenaeus japonicas (acc. no. KC409392.1, KP297916.1); $85 \%$ with Fenneropenaeus merguiensis (acc. no.KJ879290.1), and $85 \%$ with Penaeus indicus (acc. no.AF284431.1).

The 16SrRNA sequences were deposited in the same databases under the accession numbers LC198474.1, LC198475.1, and LC202982.1-LC202986.1. Egyptian $M$. latisulcatussamples showed $100 \%$ similarity with M. Hathor (acc. no. KU950453.1, JF899806.1), $99 \%$ with M. latisulcatus (acc. no.LC189475.1), and lower similarities with other penaeid species, like $94 \%$ with M. plebejus (acc. no.AF279822.1) and $93 \%$ with Penaeusmonodon (acc. no.HQ127457.1).

Phylogenetic analysis for both 16SrRNA and COI genes exhibited a close proximity among all Melicertus species, especially for Egyptian M. latisulcatuspresented in the current study and $M$. hathor, being the two species located in the same subclade in the phylogenetic trees of both analyzedgenes. Interestingly, 16SrRNA gene sequences of some M. latisulcatus collected from Egypt and Australia in other studies than the current one (acc. no. KU324868.1 and KR153528.1) were located in a single subclade with another Indo-West Pacific species, M. plebejus. In addition, a sample of M. latisulcatus collected from Hong Kong (acc. no. AF279821.1) and Egypt (acc. no. KU324867.1) in other studies than the current one were grouped together in a single subclade. Bothof these subclades differed from the subclade, which M. latisulactaus morphologically verified in the current study (Figs. 4 and 5).

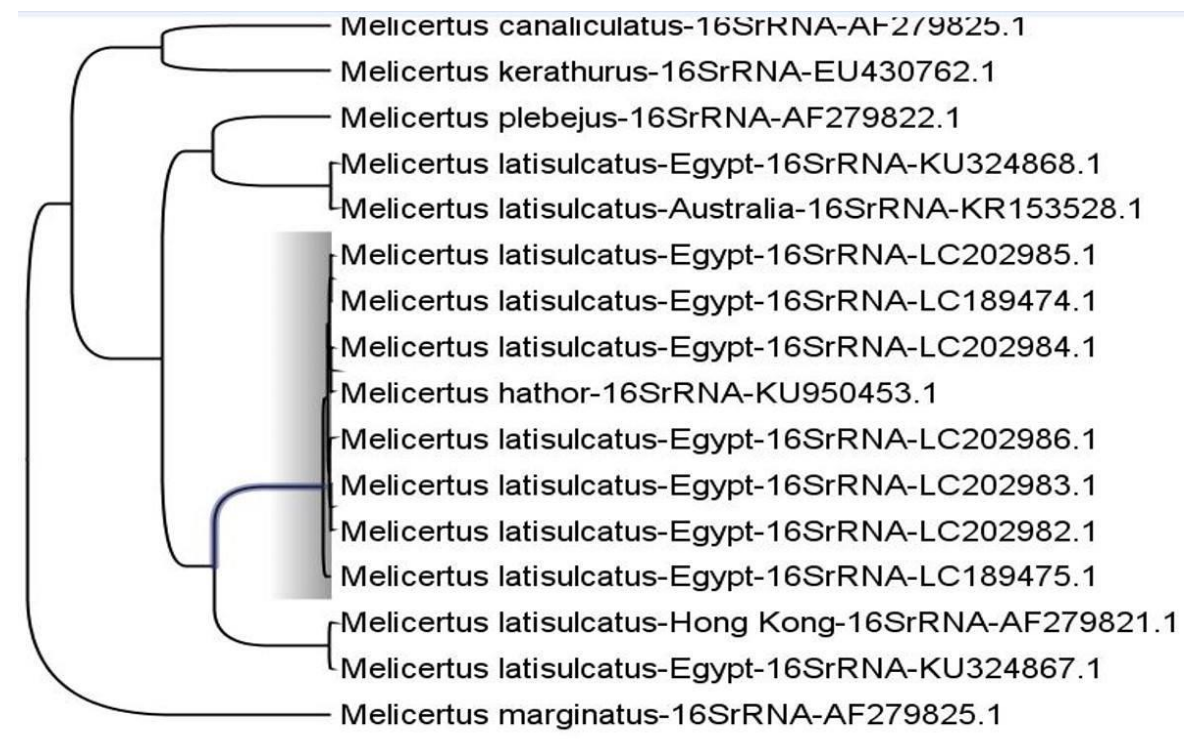

-

Fig. 4: Maximum likelihood Phylogenetic tree for 16SrRNA gene sequences of M. latisulcatus collected from the Red Sea in the current study and others retrieved from the GenBank database for the same species and others from the same genus but different species. 


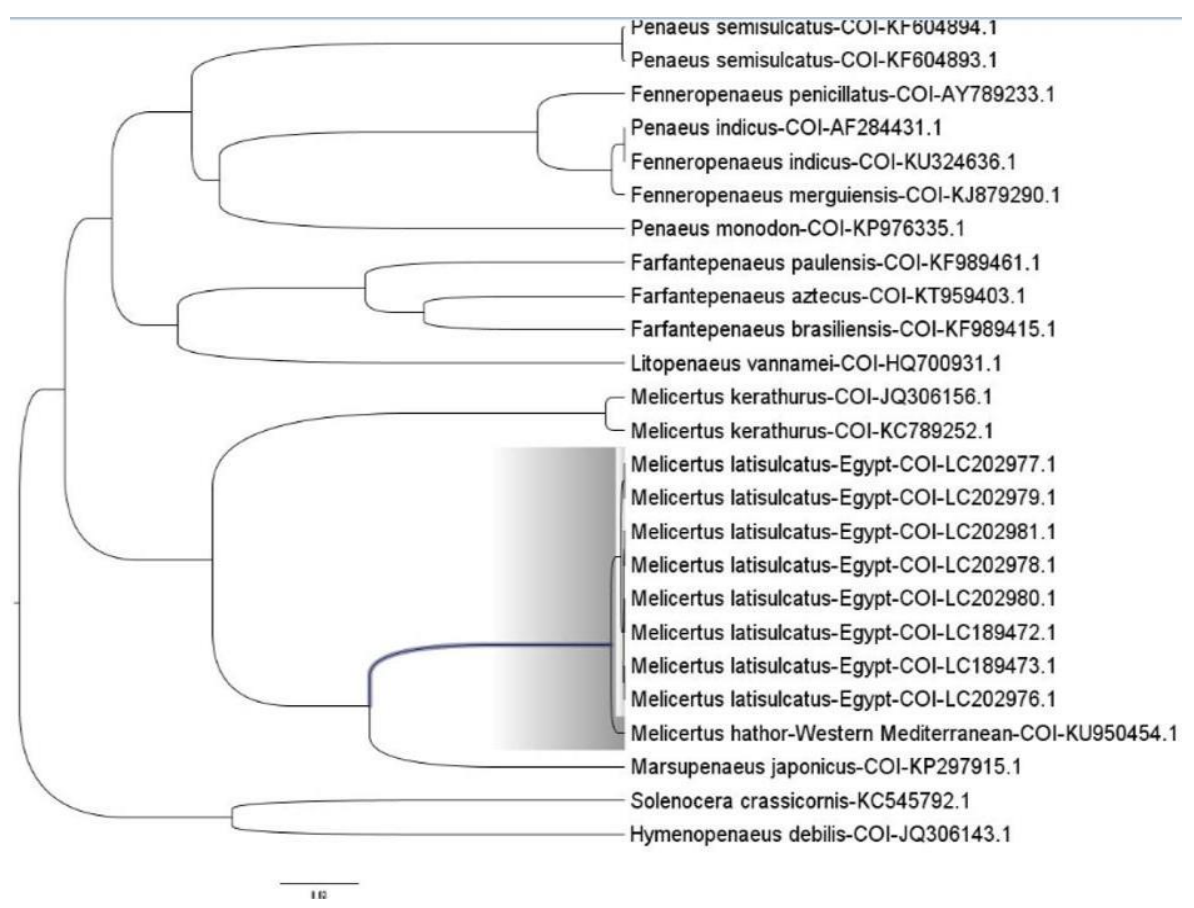

Fig. 5: Maximum likelihood Phylogenetic tree for COI gene sequences of M. latisulcatus collected from the Red Sea in the current study and others retrieved from the GenBank database for the same species and other shrimp species.

Likewise, COI-based pairwise distances were the least among M. latisulcatus, $M$. hathor, and other species belonging to genus Melicertus. These distances increased in comparison to other penaeidgenera and reached the maximum with two Western hemisphere Farfantepenaeusspecies, that are $F$. paulensisand $F$. aztecus $(0.24$ and 0.21 , respectively) (Table 2 COI pairwise distances). Similarly, the least pairwise distances at the level of 16SrRNA gene were between the Egyptian samples of M. latisulcatusand M. hathor (Table 3 ). These distances increase with other species of the genus Melicertusto reach 0.106 with $M$. marginatus. The maximum distance was with Trachypenaeuscurvirostris (LC150891.1).

Table 2: COI gene-based pairwise distances among Egyptian M. latisulcatus samples and other shrimp species belonging to genus Melicertus.

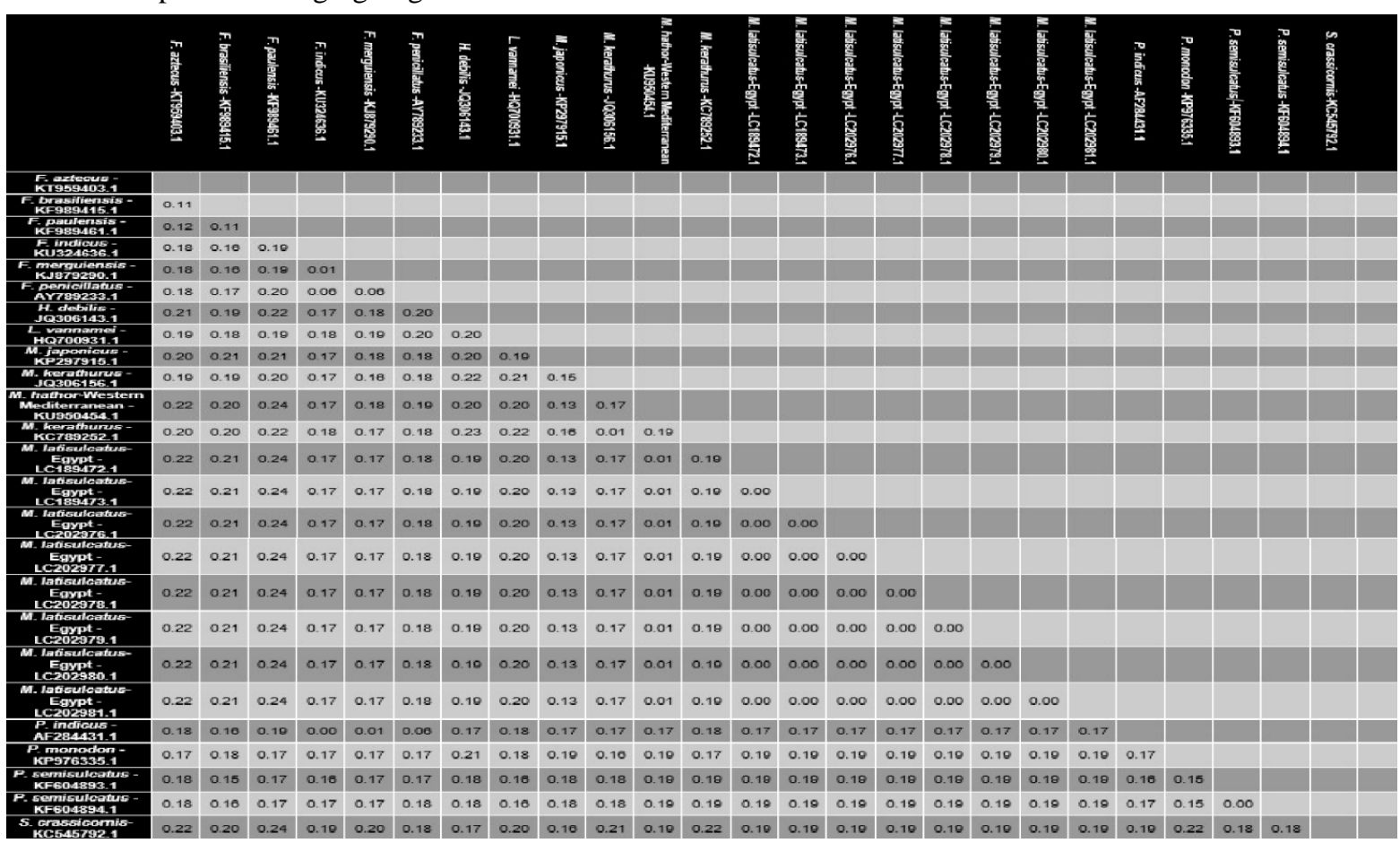


Table 3: 16SrRNA gene-based pairwise distances among Egyptian and international samples of $M$. latisulcatus and other shrimp species.

\begin{tabular}{|c|c|c|c|c|c|c|c|c|c|c|c|c|c|c|c|c|c|}
\hline \multicolumn{18}{|l|}{ T. curvirostris-Egypt-LC150891.1 } \\
\hline M. kerathurus-EU430762.1 & 0.158 & & & & & & & & & & & & & & & & \\
\hline M. latisulcatus-Egypt-KU324868.1 & 0.187 & 0.106 & & & & & & & & & & & & & & & \\
\hline M. latisulcatus-Egypt-KU324867.1 & 0.165 & 0.092 & 0.070 & & & & & & & & & & & & & & \\
\hline M. hathor-KU950453.1 & 0.158 & 0.088 & 0.081 & 0.066 & & & & & & & & & & & & & \\
\hline M. latisu/catus-Egypt-LC202982.1 & 0.158 & 0.088 & 0.081 & 0.066 & 0.000 & 0.000 & 0.000 & 0.000 & 0.000 & & & & & & & & \\
\hline M. latisu/catus-Egypt-LC189475.1 & 0.158 & 0.084 & 0.084 & 0.062 & 0.004 & 0.004 & 0.004 & 0.004 & 0.004 & 0.004 & & & & & & & \\
\hline M. latisu/catus-Egypt-LC189474.1 & 0.158 & 0.088 & 0.081 & 0.066 & 0.000 & 0.000 & 0.000 & 0.000 & 0.000 & 0.000 & 0.004 & & & & & & \\
\hline M. canaliculatus-AF279825.1 & 0.168 & 0.062 & 0.088 & 0.077 & 0.088 & 0.088 & 0.088 & 0.088 & 0.088 & 0.088 & 0.084 & 0.088 & & & & & \\
\hline M. marginatus-AF279825.1 & 0.183 & 0.106 & 0.103 & 0.106 & 0.106 & 0.106 & 0.106 & 0.106 & 0.106 & 0.106 & 0.103 & 0.106 & 0.092 & & & & \\
\hline M. plebejus-AF279822.1 & 0.165 & 0.077 & 0.055 & 0.044 & 0.059 & 0.059 & 0.059 & 0.059 & 0.059 & 0.059 & 0.055 & 0.059 & 0.070 & 0.095 & & & \\
\hline M. latisu/catus-Australia-KR153528.1 & 0.187 & 0.106 & 0.000 & 0.070 & 0.081 & 0.081 & 0.081 & 0.081 & 0.081 & 0.081 & 0.084 & 0.081 & 0.088 & 0.103 & 0.055 & & \\
\hline M. latisulcatus-Hong Kong-AF279821.1 & 0.165 & 0.092 & 0.070 & 0.000 & 0.066 & 0.066 & 0.066 & 0.066 & 0.066 & 0.066 & 0.062 & 0.066 & 0.077 & 0.106 & 0.044 & 0.070 & \\
\hline
\end{tabular}

For the first time in Egypt and the world, we provided a full morphological description and DNA barcodes for the western king prawn M. latisulcatus. Females $M$. latisulcatus collected from the Suez Gulf were larger and heavier, with the wider abdomen, than males sampled during 2014/2015. In the present study, the recurrent allometric growth for prawns ( $M$. latisulcatus) were in agreement with previous studies in the Gulf of Suez (Yassein, 1992; Zaglol, 1995) where females are heavier (higher $\mathrm{b}$ values) than males with increasing total length. In contrast, smaller b values in males were reported for M. latisulcatus in Australia (Penn and Hall, 1974; Potter et al., 1991; Kangas, 1999; Carrick, 2003), Western Indian Ocean (IvanovandKryloy, 1980), Arabian Gulf (Farmer, 1986). Such different morphometric equations were reported for a number of shrimps and prawns species (Sharawyet al., 2016and 2017), which clearly indicate the occurrence of ontogenetic sexual dimorphism of $M$. latisulcatus in the present study. Furthermore, it has been suggested that the morphometric differences are due to different growth (in size) and metabolism between males and females, especially during the sexual maturation (Acciolyet al., 2013). Moreover, Accioly et al. (2013) stated that such allometry of the sexual characteristics is an example of the interspecific heterochrony identification.

The present results of length-weight relationships (TL-WT and CL-Wt) of males and females revealed that females started to be heavier than males from 10.3 $\mathrm{cm}$ and more. At the same total length, females start to develop a wider carapace, while the males show the opposite pattern. Previous morphometric relationships showed only a general increase in the size of females when changing from immature to sexual maturity stages. Such obvious size increase in the carapace width/total length proportions (Fig. 3) is actually related to sexual maturity, unfortunately, can only be verified by gonad histology. However, these lengths $(10.3 \mathrm{~cm}$ TL $=3.8 \mathrm{~cm}$ CL) are almost identical to the length of M. latisulcatus, in which $50 \%$ of all femaleswere mature, that estimated in the Spencer Gulf $\left(\mathrm{CL}_{50}=3.65 \mathrm{~cm}\right.$, Carrick, 2003), the Queensland's East Coast $\left(\mathrm{CL}_{50}=3.4 \mathrm{~cm}\right.$, Courtney and Dredge, 1988) and 
the Suez Gulf $\left(\mathrm{TL}_{50}=10.8 \mathrm{~cm}\right.$, Yassien, 1992). While small ripe females were recorded by Penn (1980) in the Western Australian population $\left(\mathrm{CL}_{50}=2.9 \mathrm{~cm}\right)$. In fact, asimilar pattern occurs for a number of commercially important penaeid species (Acciolyet al., 2013; Sharawy et al., 2016 and 2017).

In the present work, the recorded ratio deviation toward females (1.9:1) is common in penaeid species (see Sharawyet al., 2016 and 2017), which may be attributedto the differences in life cycle, reproductive patterns, migration, mortality, nets selectivity and the aforementioned growth rates.

Barcoding of species belonging to the crustacean genus Melicertusis still very poor (e.g. Keskin and Atar, 2013). Genus Melicertus encompasses nine species, namely: M. canaliculatus, $M$. hathor, M. kerathurus, M. latisulcatus, M. longistylus, M. marginatus, M. plebejus, M. similis and M. tigrinus. Recently, barcoding coupled to morphological clues for authentication of species belonging to this genus is completely lacking. Therefore, this study, to the best of our knowledge, is the first to provide both morphological and genetic markers for identification of M. latisulcatus, and also for identification of the genus Melicertusin the world. It is worth to mention that, not only COI was proven as a good marker for discrimination of crustacean species (Sharawy et al., 2017) butalso 16SrRNA gene has been suggested as abetter marker especially for higher crustacean species. Therefore, we used both markers; in order to provide adequate molecular clues for M. latisulcatus identification.

Yet, the present phylogenetic trees showed two very interesting points:a) both 16 Sr RNA gene and COI-based phylogenetic trees placed $M$. hathor and $M$. latisulcatus in the same subclade. BLAST comparisons were completely in agreement with our phylogenetic data, showing about $99 \%$ sequences identity among $M$. latisulcatus samples analyzed in the current study and $M$. hathor present in the GenBank database, andb) some Egyptian $M$. latisulcatis16SrRNA gene sequences that we retrieved from the GenBank database were divergent from the samples we morphologically and genetically authenticated as M. latisulcatus. Both points may suggest some phenotypic plasticity of this species, and confirm the need for including both morphological and genetic descriptions for future identification and authentication of both species $M$. latisulcatus and $M$. hathor.

Penaeid shrimps and prawns are well-known as an active migratory species. As previously mentioned, they perform an inshore reproductive migration towards estuaries to reproduce, and their juveniles carry out an offshore migration towards the deep waters of the open sea. Moreover, some penaeids can migrate through very long distances. For example, an individual sample of P.plebejuswas recaptured about 900 $\mathrm{km}$ away from the first site where they were initially recorded (Ruello, 1975). Likewise, $M$. hathor crossed the Suez Canal from its original habitats in the Red Sea, and even the nearest Mediterranean shores, and reached the Northern Mediterranean, where it was recorded in Turkey (Gokogluand Kaya, 2008). Therefore, the widespread of the M. latisulcatusin the entire area of the Western Indo-Pacific and the Indian Ocean to the Red Sea and the Mediterranean Sea may be attributed to the active migratory capability of such species. Until now, there are no enough studies that cover the morphological/genetic variations in this species in a wide geographical range to give clear vision about its origin and expansion; possibly owing to the scarcity of genetic data. So far, this study could provide a step forward for the identification of spatial distribution patterns of this species, in additn to identifying its genetic diversity as tools for its management, economic uses, and conservation.

In Conclusion and for the first time, the present work verified the variability of the relative growth between $M$. latisulcatus sexes and estimated the size of sexual 
maturity based on a morphometric analysis, which represents an important tool for the management of such commercial species. Moreover, genetic barcodes based on both 16SrRNA and COI genes were provided for the first time in the Red Sea area in Egypt. The phylogeny based on mitochondrial DNA sequences provides a plurality of phylogenetically instructive characters, even with the species under the study or within the genus Melicertus. On the other hand, one of the outcome results from the present study isadding moresequences to the GenBank database regarding the Egyptian marine invertebrates especially from the Gulf of Suez, Red Sea. Our results also suggested that length-weight relationships could be used as an important criterionfor selective breeding programs. Furthermore, based on these results, subsequent studies will be able to estimate the sexual differentiation through early ontogenetic stage; in order to 1) separate females from males during culture, ensuring similar prawn size in tanks/ponds, and 2) boost a protocol to secure monosex (all females) stocks which have a significant impact on shrimp and prawn culture sector so far.

\section{REFERENCES}

Abbas, E. M.; Abdelsalam K. M.; Mohammed-Geba K.; Ahmed H. O.andKato, M. (2016). Genetic and morphological identification of some crabs from the Gulf of Suez, Northern Red Sea, Egypt.Egypt. J. Aquatic Res., 42 (3): 319-329.

Abdel-Razek, F. A.; Abdel Rahman; S. H. and Zaglol S. S. (1996). Aspects of the Reproduction of the Prawn Penaeus latisulcatus Kishinouya in the Gulf of Suez, Egypt. Journal of King Abdulaziz University: Marine Science, 7:153-159.

Accioly, I. V.; Lima-Filho, P. A.; Santos, T. L; Barbosa, A.C. A.; Campos, L.B.S.; Souza, J. V.; Araújo, W. C. and Moilna, W. F. (2013). Sexual dimorphism in Litopenaeusvannamei (Decapoda) identified by geometric morphometrics.PanAmerican Journal of Aquatic Sciences, 8(4): 276-281.

Carrick, N. A. (2003). Spencer Gulf Prawn (Melicertuslatisulcatus) Fishery. Fishery Assessment report to PIRSA. SARDI Aquatic Sciences RD03/0079-2.

Courtney, A. J.and Dredge, M.C. L. (1988). Female reproduction biology and spawning periodicity of two species of king prawns, Penaeuslongistylus Kubo and Penaeuslatisulcatus Kishinouye, from Queensland's East Coast Fishery. Australian Journal of Marine and Freshwater Research, 39: 729-741.

Dall, W.; Hill, B. J.; Rothlisberg, P. C. and Staples D. J. (1990). The Biology of the Penaeidae. In: Blaxter J.H.S. and Southward A. J. (eds.). Advances in marine biology, 27: 1-489.

Dixon, C. D.; Roberts, S. D. and Hooper G. E.(2011). Gulf St Vincent Prawn Penaeus (Melicertus) latisulicatus Fishery.SARDI Publication No. F2007/ 000782-4. Research Series No. 526 Adelaide, South Australia: South Australian Research and Development Institute (Aquatic Sciences).

El-Ganainy, A.A.andYassien, M. H. (2012). The population biology of penaeid prawns in the Gulf of Suez, Red Sea, Egypt. Marine Biology Research, 8(4): 405-411.

FAO. (2014). The State of World Fisheries and Aquaculture. Food and Agriculture Organization of the United Nations, Rome.

Farmer, A. S. D. (1986). Morphometric relationships of commercially important species of penaeid shrimps from the Arabian Gulf, Kuwait.Bulletin of Marine Science, 7: 1-21. 
Flegel, T. W. (2007).The right to refuse revision in genus Penaeus. Aquaculture, 264: 2-8.

Folmer, O.; Black, M.; Hoeh, W.; Lutz, R. andVrijenhoek, R. (1994). DNA primers for amplification of mitochondrial cytochrome $\mathrm{C}$ oxidase subunit I from diverse metazoan invertebrates.Molecular Marine Biology and Biotechnology,3: 294299.

GAFRD (2014). Annual report of Bardawil lagoon, The General Authority for the Development of fish Resources, Arab Republic of Egypt.

Gokoglu, M. and Kaya, Y. (2008). First record of Melicertushathor (Penaeidae) from the Gulf of Antalya (Mediterranean Sea). Marine Biodiversity Records, 1: e17.

Hajibabaei, M.; Singer, G. A.; Hebert, P. D.; Hickey, D. A.(2007).DNA barcoding: how it complements taxonomy, molecular phylogenetics and population genetics.Trends in Genetics,23(4): 167-172.

Ivanov, B. G. and Krylov, V. V. (1980). Length-weight relationship in some common prawns and lobsters (Macrura, Natantia and Reptantia) from the western Indian Ocean.Crustaceana, 38(3): 279-289.

Kangas, M. (1999). Postlarval and juvenile western king prawns Penaeus latisulcatus Kishinouye studies in Gulf St Vincent, South Australia with reference to the commercial fishery. PhD thesis, University of Adelaide.

Keskin, E. and Atar, H. H. (2013). DNA barcoding commercially important aquatic invertebrates of Turkey.Mitochondrial DNA, 24(4): 440-450.

Nizinski, M. S. (2003). Annotated checklist of decapod crustaceans of Atlantic coastal and continental shelf waters of the United States.Proceedings of the Biological Society of Washington,116(1): 96-157.

Penn, J.W. and Hall, N. G. (1974). Morphometric data relating to the Western King Prawn, Penaeuslatisulcatus (Kishinouye 1900) and the Brown Tiger Prawn, Penaeusesculentus (Haswell 1879) from Shark Bay, Western Australia.Fishery Bulletin. Department of Fisheries and Fauna (Western Australia),15: 1-12.

Penn, J. W. (1980). Spawning and fecundity of the western king prawn, Penaeuslatisulcatus Kishinouye, in the Western Australian water. Australian Journal of Marine and Freshwater Research,31: 21-35.

Pérez Farfante, I. and Kensley, B. (1997). Penaeoid and sergestoid shrimps and prawns of the world. Keys and diagnoses for the families and genera. Editions du Muséum National d'HistoireNaturelle, $233 \mathrm{pp}$.

Potter, I. C.; Manning, J. C. and Loneragan, N. R. (1991). Size, movements, distribution and gonadal stage of the western king prawn (Penaeusfatidcatus) in a temperate estuary and local marine waters.Journal of Zoology, 223: 419-445

Primavera, J. H. andLebata, M.J.H. L.(2000).Size and diel differences in activity patterns of Metapenaeusensis, Penaeuslatisulcatus and P. merguiensis.Marine and FreshwaterBehaviourand Physiology,33(3): 173-185.

Ruello, N. V. (1975). Geographical distribution, growth and breeding migration of the eastern king prawn, Penaeusplebejus Hess. Australian Journal of Marine and Freshwater Research, 26: 343-354.

Sambrook, J.; Fritschi, E. F. andManiatis, T. (1989).Molecular Cloning: A LaboratoryManual. Cold Spring Harbor Laboratory Press, New York.

Sharawy, Z. Z.; Abbas, E. M.;Khafage, A. R., Galal-Khallaf A.; Ismail R. F.; Ahmed, H. O.; Mohammed-Geba, K. and Kato, M. (2017). Descriptive analysis, DNA barcoding and condition index of Penaeids (Crustacea: Decapoda) from the Egyptian Mediterranean coast. Fisheries Research, 188: 6-16. 
Sharawy, Z.; Abbas, E.M.; Desouky, M.G.and Kato, M. (2016). Descriptive analysis and molecular identification of the green tiger shrimp Penaeussemisulcatus (De Haan, 1844) in Suez Gulf, Red Sea. International Journal of Fisheriesand Aquatic Studies, 4(5): 426-432.

Sundaramootrhy, B.; Venkataramani, V. K.; Jawahar, P. and Neethiselvan, N. (2013). Study on Population Characteristics and Fishery of Western King Shrimp Penaeus (Melicertus) latisulcatusKishinouye, 1896, along Thoothukudi coast, Southeast India. International Journal of Fisheries and Aquatic Studies,1(2): 2124.

Tamura, K.; Stecher, G.; Peterson, D.; Filipski, A. and Kumar, S. (2013). MEGA6: molecular evolutionary genetics analysis version 6.0. Molecular Biology and Evolution, 30(12): 2725-2729.

Tanner, J. E. and Deakin, S. (2001). Active habitat selection for sand juvenile western king prawns, Melicertus latisulcatus (Kishinouye). Journal of Experimental Marine Biology and Ecology, 261: 199-209.

Tavares, A. I.; Cabezas, M. P.; Xavier, R.;Branco, M.; Lima, F. P.;Seabra, R.; Ribeiro, P. A.; Lopes, E. P.and Santos, A. M. (2017). Phylogeography and phylogeny of the genus Acanthonyx (Decapoda, Epialtidae) in the north- east Atlantic and Mediterranean.Zoologica Scripta, DOI: 10.1111/zsc.12232

Thompson, J. D.; Higgins, D.G. and Gibson, T. J. (1994). CLUSTAL W: improving the sensitivity of progressive multiple sequence alignment through sequence weighting, position-specific gap penalties and weight matrix choice. Nucleic Acids Research, 22(22): 4673-4680.

Yassien, M. H. (1992). Biological studies on some shrimp species from the Gulf of Suez, Egypt. M. Sc. Thesis, Suez Canal University, Egypt.

Zaghloul, S. S. (1995). Studies on reproduction and larval stages of some penaeid prawns inSuez Gulf. M. Sc. Thesis, Suez Canal University, Egypt.

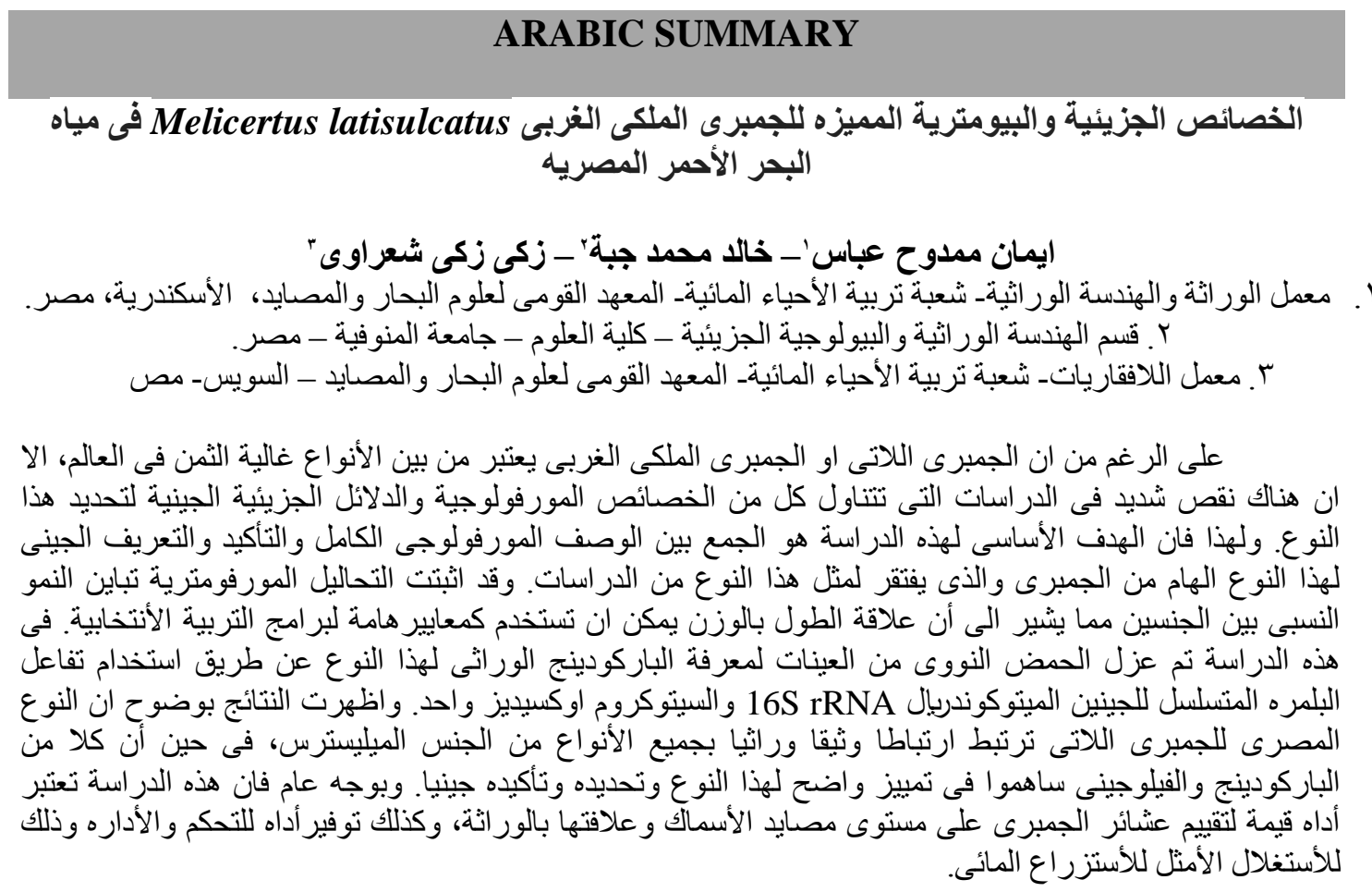

